\title{
PREGNANCY BLOCK IN MICE: CHANGES IN PITUITARY LH AND LTH AND PLASMA PROGESTIN LEVELS
}

\author{
V. M. GHAPMAN, GLAUDE DESJARDINS AND W. K. WHITTEN \\ Department of Biology, Yale University, New Haven, Connecticut, \\ Department of Physiology and Pharmacology, Oklahoma State University, \\ Stillwater, Oklahoma, and \\ The Jackson Laboratory, Bar Harbor, Maine \\ (Received 17th Fune 1969, revised 23rd October 1969)
}

\begin{abstract}
Summary. A significant decrease in pituitary LH accompanied by an increase in blood plasma progestins was observed in pregnant females $24 \mathrm{hr}$ after exposure to alien males (Day 2 post-mating). Conversely, no change in pituitary LtH was detectable until $48 \mathrm{hr}$ after females were caged with alien males. These data suggest the LH release may play an important rôle in pregnancy block.
\end{abstract}

Pregnancy may be blocked in laboratory mice by isolating recently mated females from their stud males and exposing them to alien males (Bruce, 1959, 1960). Pregnancy can also be blocked by exposing recently mated females either to the urine of alien males (Dominic, 1964) or to a cage which has been soiled by alien males (Parkes \& Bruce, 1962). However, after implantation has been accomplished, alien males no longer interfere with the maintenance of pregnancy. These findings suggest that the effect of the alien male is an interference with the endocrine maintenance of pregnancy sometime before implantation.

Studies on the mechanisms responsible for pregnancy block have demonstrated that the effects of exposure to alien males can be overridden by either injecting prolactin (LtH) (Parkes \& Bruce, 1961) or by grafting pituitary tissue to the kidney capsule (Dominic, 1967). Furthermore, pregnancy block does not occur in lactating females where LtH levels are normally increased (Bruce \& Parkes, 1961). On the basis of these data, Dominic (1967) suggested that the primary mechanism for pregnancy block was an inhibition of pituitary Lttr release and the subsequent failure of the corpora lutea.

The present experiments were primarily designed to test the hypothesis that exposure of recently mated females to alien males would result in changes in pituitary LtH concentration. A secondary objective of this study was to determine whether or not changes in the levels of pituitary LH and plasma progestins coincided with implantation failure initiated by exposing pregnant mice to alien males. Our results show that changes in pituitary LH and plasma progestins occur within $24 \mathrm{hr}$ of exposing mated females to alien males while 
changes in pituitary LtH levels were not detected until $48 \mathrm{hr}$ after male exposure. An alternative to LtH inhibition as the mechanism of pregnancy block is proposed.

Female SJL/J mice, between 6 and 18 weeks old, were reared in groups of four to six in $15 \times 15 \times 30 \mathrm{~cm}$ stainless steel cages with $14 \mathrm{hr}$ of light every $24 \mathrm{hr}$. At 18 weeks of age, the females were paired with $\mathrm{SJL} / \mathrm{J}$ males of the same age. Females were examined each morning for vaginal plugs. After detecting a vaginal plug, a female was assigned at random to one of the following treatment groups: (1) Day 0, (2) Day 2-control, (3) Day 2-exposed to alien male, (4) Day 3-control, and (5) Day 3-exposed to alien male. Day-0 females were killed the morning a vaginal plug was observed. The Day- 2 and Day-3 control females were left with their SJL/J stud male and killed either 2 or 3 days after the plug was observed. The Day-2 and Day-3 females exposed to an alien male were removed from their SJL/J stud male's cage $24 \mathrm{hr}$ after the plug was observed, placed in a BALB/cJ male's cage and killed either 24 or $48 \mathrm{hr}$ later. The $\mathrm{BALB} / \mathrm{cJ}$ males were kept in a separate room from the SJL/J pairs to avoid mixing male odours in the same room which would lower the efficiency of the pregnancy block. All mice were killed by decapitation between 10.00 and 12.00 hours and blood was collected by drainage into heparinized tubes. The heparinized tubes were centrifuged at $10,000 \mathrm{~g}$ for $10 \mathrm{~min}$ at $5^{\circ} \mathrm{C}$ and the plasma was removed and stored at $-25^{\circ} \mathrm{C}$. Plasma progestin concentrations were determined by the method of Murphy (1967).

Pituitary glands were removed and pooled by treatment groups and frozen at $-25^{\circ} \mathrm{G}$. At the time of assay, pituitaries were weighed, homogenized (10 $\mathrm{mg} / \mathrm{ml}$ in $0.85 \%$ sodium chloride prepared with pyrogen-free water) centrifuged at $5000 \mathrm{~g}$ for $15 \mathrm{~min}$ at $5^{\circ} \mathrm{G}$ and the supernatant fluid assayed for LH and LtH activity.

Luteinizing hormone was measured for each treatment in duplicate by the 4-hr ovarian ascorbic acid depletion method of Parlow (1961), employing five rats (Sprague Dawley) for each dose level of unknown or standard. Pituitary LH potencies were measured with 0.2 and $0.8 \mathrm{mg}$-equivalents of fresh tissue and these were compared with 0.4 and $1.6 \mu \mathrm{g}$ of $\mathrm{NIH}-\mathrm{LH}-\mathrm{sl} 1$.

Prolactin (LtH) was determined twice in each treatment group by the pigeon crop sac 'micro' method of Reece \& Turner (1937). The pigeons (White-King) were 5 to 6 weeks old at the time of assay. Pituitary LtH concentrations were measured with 0.2 and $0.8 \mathrm{mg}$-equivalents of fresh tissue and these were compared with 1 and $4 \mu \mathrm{g}$ of NIH-P-s3. For each assay, eight pigeons were used at each dose level of the unknown or standard.

No significant changes were observed in the concentration of pituitary LtH on Days 0,2 , or 3 for the control animals (Table 1). Similarly, there were no measurable changes in the concentration of pituitary LtH between the Day-0 and Day-2 females that were exposed to alien males. However, the 3-day group exposed to males had a higher concentration of pituitary LtH than did the 3 -day control females ( 1.47 versus $0.85 \mu \mathrm{g} / \mathrm{mg}$ ).

The pituitary LH concentration of control females ranged from 0.35 to 0.20 $\mu \mathrm{g} / \mathrm{ml}$ between Day 0 and Day 3 post-mating $(P>0 \cdot 25$, Table 1$)$. In contrast to the relatively constant level of LH in the pituitaries of control females, the 
pituitary LH concentration of females exposed to alien males for $24 \mathrm{hr}$ was significantly less than that of females killed on the morning after copulation $(0.06$ versus $0.35 \mu \mathrm{g} / \mathrm{mg} ; P<0.01)$ and also less than that of the unexposed females $(0.06$ versus $0.25 \mu \mathrm{g} / \mathrm{mg} ; P<0.05)$. After $48 \mathrm{hr}$ of exposure to alien males, however, the pituitary LH content reached a peak of $0.70 \mu \mathrm{g} / \mathrm{mg}$ so that it was significantly higher than that of the $48-\mathrm{hr}$ control animals $(0.20 \mu \mathrm{g} / \mathrm{mg})$ and of animals exposed for $24 \mathrm{hr}(0.06 \mu \mathrm{g} / \mathrm{mg} ; P<0 \cdot 01)$.

\section{TABLE 1}

CONGENTRATIONS OF PITUITARy LUTEINIZING HORMONe (LH), PROLAGTiN (LTH), AND BLOOD PLASMA PROGESTINS IN PREGNANT FEMALE MICE EXPOSED TO ALIEN MALES

\begin{tabular}{|c|c|c|c|c|}
\hline Treatment & $\begin{array}{l}\text { No. of } \\
\text { females }\end{array}$ & $\begin{array}{c}\text { LH concentration } 1 \\
\text { Potency } 95 \% \text { limits }\end{array}$ & $\begin{array}{r}\text { LtH concentration }{ }^{3} \\
\text { Potency } 95 \% \text { limits }\end{array}$ & $\begin{array}{l}\text { Progestin concentration } \\
\quad(n g / m l) \pm S . E .\end{array}$ \\
\hline \multirow[t]{2}{*}{$\begin{array}{l}\text { Day } 0 \text {, vaginal plug } \\
\text { detected }\end{array}$} & 15 & $\begin{array}{ll}0.41 & 0.28 \text { to } 0.66 \\
0.32 & 0.23 \text { to } 0.47\end{array}$ & $\begin{array}{ll}0.93 & 0.41 \text { to } 1.84 \\
0.78 & 0.32 \text { to } 1.28\end{array}$ & \\
\hline & Mean & 0.350 .24 to $0.52^{2}$ & 0.840 .34 to $1.49^{4}$ & $5 \cdot 1 \pm 0.12$ \\
\hline \multirow[t]{2}{*}{ Day 2, control } & & $\begin{array}{ll}0.22 & 0.16 \text { to } 0.30 \\
0.29 & 0.20 \text { to } 0.46\end{array}$ & 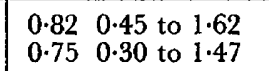 & \\
\hline & Mean & 0.250 .19 to 0.35 & 0.760 .35 to 1.42 & $8 \cdot 5 \pm 1 \cdot 15$ \\
\hline \multirow[t]{2}{*}{$\begin{array}{l}\text { Day 2, exposed to alien } \\
\text { male }\end{array}$} & 13 & $\begin{array}{ll}0.04 & 0.01 \text { to } 0.17 \\
0.08 & 0.03 \text { to } 0.18\end{array}$ & $\begin{array}{ll}0.59 & 0.34 \text { to } 1.20 \\
0.79 & 0.30 \text { to } 1.40\end{array}$ & \\
\hline & Mean & $0.06 \quad 0.02$ to 0.13 & 0.680 .30 to 1.24 & $13 \cdot 7 \pm 0.93$ \\
\hline \multirow[t]{2}{*}{ Day 3, control } & 15 & $\begin{array}{ll}0.23 & 0.10 \\
0.19 & 0.08 \text { to } 0.38 \\
0.37\end{array}$ & $\begin{array}{ll}0.91 & 0.40 \\
0.80 & 0.33 \text { to } 1.80 \\
1.51\end{array}$ & \\
\hline & Mean & $0.20 \quad 0.10$ to 0.34 & 0.850 .34 to 1.58 & $23 \cdot 5 \pm 1 \cdot 3$ \\
\hline \multirow[t]{2}{*}{$\begin{array}{l}\text { Day 3, exposed to alien } \\
\text { male }\end{array}$} & 15 & $\begin{array}{ll}0.63 & 0.52 \text { to } 1.09 \\
0.77 & 0.58 \text { to } 1.32\end{array}$ & $\begin{array}{ll}1.26 & 0.89 \text { to } 2.40 \\
1.91 & 1.12 \text { to } 3.62\end{array}$ & \\
\hline & Mean & 0.700 .55 to 1.20 & 1.471 .00 to 2.87 & $5 \cdot 7 \pm 0 \cdot 2$ \\
\hline
\end{tabular}

1 Potency and $95 \%$ confidence limits expressed as $\mu$ g-equivalents of NIH-LH-s $11 / \mathrm{mg}$ of pituitary tissue (wet weight).

${ }_{2}^{2}$ Mean LH concentration expressed as the combined potency of two replicate assays and their $95 \%$ confidence intervals.

${ }^{3}$ Potency and $95 \%$ confidence limits expressed as $\mu$ g-equivalents of NIH-P-s $3 / \mathrm{mg}$ of pituitary tissue (wet weight).

4 Mean prolactin concentration expressed as the combined potency of two replicate assays and their $95 \%$ confidence interval.

5 Mean progestin concentration based upon duplicate measurements of three pools of plasma from each treatment. This method measures total progestins which include progesterone and $17 \alpha-\mathrm{OH}$ progesterone.

The plasma progestin concentration increased from $5 \cdot 1$ to $8.5 \mathrm{ng} / \mathrm{ml}$ (Table 1 ) between Day 0 and Day 2 of pregnancy in the control females $(P<0.01)$, and between Days 2 and 3 of pregnancy, the plasma progestin concentration increased three-fold to $23.5 \mathrm{ng} / \mathrm{ml}(P<0.01$; Table 1$)$. At $24 \mathrm{hr}$ following exposure to alien males, the females had higher blood plasma progestin concentrations than control females, 8.5 versus $13.7 \mathrm{ng} / \mathrm{ml}(P<0.01)$ but by Day 3 post-mating, the females exposed to the alien male had $5.7 \mathrm{ng} / \mathrm{ml}$ compared with $23.5 \mathrm{ng} / \mathrm{ml}$ blood progestins in control females $(P<0.01)$.

The observation that pituitary LtH concentration was increased on Day 3 in 
females exposed to alien males suggests that LtH release may have been depressed by alien males. This interpretation is in agreement with the findings that pregnancy block can be prevented by exogenous LtH (Parkes \& Bruce, 1962), lactation (Bruce \& Parkes, 1961) and by ectopic pituitary grafts (Dominic, 1967). These data are consistent with the proposal by Dominic (1967) that interference with LtH secretion is the primary cause of pregnancy blocks. However, our data indicate that the mechanism of pregnancy block may also include altered secretion of other anterior pituitary hormones whose action may precede $\mathrm{LtH}$ blockage.

In this study, decreased pituitary LH and increased plasma progestin concentrations were noted in females within $24 \mathrm{hr}$ of exposure to alien males, during which time no comparable change in LtH was observed. Females with blocked pregnancies return to oestrus and typically show copulation plugs on Day 4 post-mating. However, in females exposed to alien males, the depletion of pituitary LH occurred at least $48 \mathrm{hr}$ before ovulation could be expected. The ability of the female pituitary-gonadal axis to respond with pronounced changes after $24 \mathrm{hr}$ of exposure to an alien male is not surprising since Bruce (1960) could obtain pregnancy block in females exposed to alien males for as little as $12 \mathrm{hr}$. Our findings suggest that pituitary LH release in post-insemination females is triggered by exposure to alien males, and it is tempting to speculate that this release may be a primary endocrine response in the sequence of events that leads to pregnancy block.

Additional evidence indirectly supports the possibility that LH release can be a primary factor in pregnancy block. Luteinizing hormone can modify the corpora lutea in pregnant rats either by depleting its secretory potential or by exerting a generalized luteolytic effect. Our findings of decreased pituitary LH and increased plasma progestins on Day 2 also correspond with the observations that progesterone administered on the day after mating induces luteal involution in mice (Burdick, 1942) and in guinea-pigs (Aldred, Sammelwitz \& Nalbandov, 1961; Nalbandov, 1961).

The control females in this study exhibited a slight decline in pituitary LH between Day 0 and Day 3. These observations suggest that a continuing release of LH normally occurs in early pregnancy. The effect of the alien male may be an over-stimulation of the normal release. This would also explain why pregnancy block does not occur after 4 or 5 days post-mating when pituitary LH concentration is decreased and plasma progesterone levels are high. This study cannot exclude other explanations for pregnancy block; nevertheless, these data do indicate that the rôle of $\mathrm{LH}$ release should not be ignored in future studies of the physiological mechanism responsible for this phenomenon.

This investigation was supported in part by Public Health Service Training Grant TIGA-5013 from the National Cancer Institute, in part by Public Health Service General Research Support Grant FR-055450-05, and in part by Public Health Service Research Grant HD-00636 from the National Institute of Child Health and Human Development. The principles of laboratory animal care as promulgated by the Council of the American Physiological Society are observed in our laboratories. 


\section{REFERENCES}

Aldred, J. P., SAmmelwitz, P. H. \& Nalbandov, A. V. (1961) Mechanism of formation of corpora lutea in guinea-pigs. F. Reprod. Fert. 2, 394.

Bruce, H. M. (1959) An exteroceptive block to pregnancy in the mouse. Nature, Lond. 184, 105.

BRUCE, H. M. (1960) A block to pregnancy in the mouse caused by proximity of strange males. F. Reprod. Fert. 1, 96.

BRUce, H. M. \& PARKes, A. S. (1961) The effect of concurrent lactation on the olfactory block to pregnancy in the mouse. 7. Endocr. 22, vi.

BuRdick, H. O. (1942) Effect of progesterone on the ovaries and embryos of mice in early pregnancy. Endocrinology, 30, 619.

Dominic, C. J. (1964) Source of the male odour causing pregnancy block in mice. (Abstract). F. Reprod. Fert. 8, 266.

Dominic, C. J. (1967) Effect of ectopic pituitary grafts on the olfactory block to pregnancy in mice. Nature, Lond. 213, 1242.

Murphy, B. P. (1967) Some studies of the protein binding of steroids and their application to the routine micro and ultramicro measurement of various steroids in body fluids by competitive protein binding radioassay. F. clin. Endocr. Metab. 27, 973.

NALBandov, A. V. (1961) Comparative physiology and endocrinology of domestic animals. Recent Prog. Horm. Res. 17, 119.

Parkes, A. S. \& BRUCE, H. M. (1961) Olfactory stimuli in mammalian reproduction. Science, N.Y. 134, 1049 .

Parkes, A. S. \& Bruce, H. M. (1962) Pregnancy block in female mice placed in boxes soiled by males. 7. Reprod. Fert. 4, 303.

PARLOW, A. F. (1961) Bioassay of pituitary luteinizing hormone by depletion of ovarian ascorbic acid. In: Human Pituitary Gonadotropins, p. 300. Ed. A. Albert. C. G. Thomas, Springfield, Illinois.

REECE, R. P. \& TURNeR, C. W. (1937) The lactogenic and thyrotropic hormone content of the anterior lobe of the pituitary gland. Bull. Mo. agric. Exp. Stn, 266. 